Regards sur l'économie allemande

Bulletin économique du CIRAC

118-119| 2015

Varia

\title{
Rapports OCDE
}

OCDE, Economic Policy Reforms 2015 - Going for Growth ; OCDE, Measuring the Digital Economy - A New Perspective

\section{Solène Hazouard}

\section{(2) OpenEdition}

Journals

Édition électronique

URL : http://journals.openedition.org/rea/4941

DOI : $10.4000 /$ rea. 4941

ISSN : 1965-0787

Éditeur

CIRAC

\section{Édition imprimée}

Date de publication : 31 décembre 2015

Pagination : 47

ISSN : 1156-8992

\section{Référence électronique}

Solène Hazouard, «Rapports OCDE », Regards sur l'économie allemande [En ligne], 118-119 | décembre 2015, mis en ligne le 31 décembre 2015, consulté le 25 septembre 2020. URL : http:// journals.openedition.org/rea/4941 ; DOI : https://doi.org/10.4000/rea.4941

Ce document a été généré automatiquement le 25 septembre 2020.

(c) CIRAC 


\section{Rapports OCDE}

OCDE, Economic Policy Reforms 2015 - Going for Growth ; OCDE, Measuring the Digital Economy - A New Perspective

\section{Solène Hazouard}

\section{RÉFÉRENCE}

OCDE, Economic Policy Reforms 2015 - Going for Growth, OCDE, Paris, 2015, 339 p. OCDE, Measuring the Digital Economy - A New Perspective, OCDE, Paris, 2014, 156 p.

1 Le rapport Going for Growth de l'ODCE observe depuis 10 ans les politiques structurelles mises en œuvre dans les pays membres de l'organisation et quelques autres grands pays, dans le but de promouvoir la croissance et d'améliorer la qualité de vie des citoyens concernés. Un second rapport de l'OCDE, ayant trait plus spécifiquement à l'économie numérique, fournit pour sa part des statistiques actuelles en la matière, associées à une solide analyse transnationale. Des données précieuses pour tout travail de recherche comparative. 